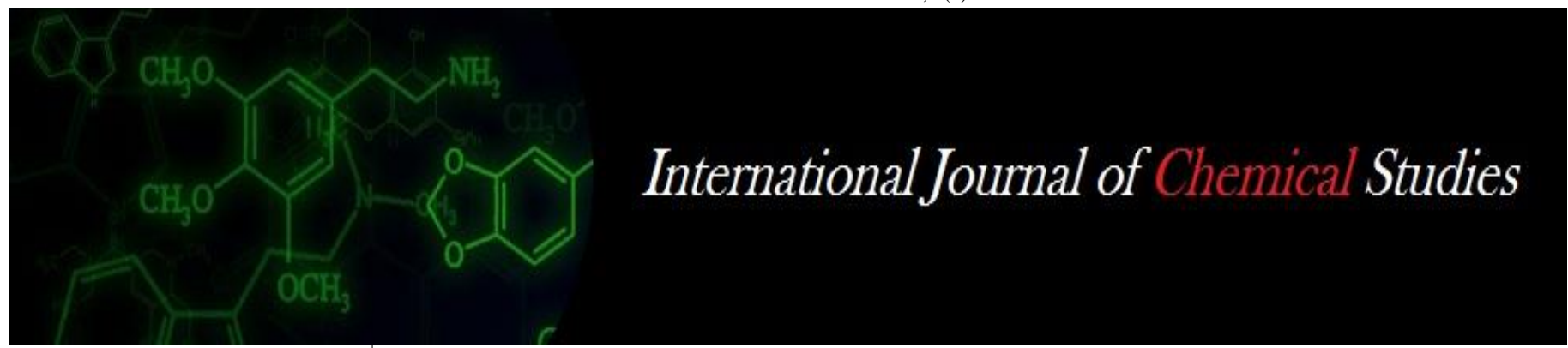

P-ISSN: 2349-8528

E-ISSN: 2321-4902

www.chemijournal.com

IJCS 2020; 8(3): 134-140

(C) 2020 IJCS

Received: 16-03-2020

Accepted: 18-04-2020

\section{Duke Okoro}

Department of Chemistry, College of Science, Federal University of Petroleum

Resources, PMB 1221, Effurun, Nigeria

Temabor Nyerhovwo Ovuowo Department of Chemistry, College of Science, Federal University of Petroleum Resources, PMB 1221, Effurun, Nigeria

Corresponding Author: Duke Okoro

Department of Chemistry, College of Science, Federal University of Petroleum Resources, PMB 1221, Effurun, Nigeria

\section{Polycyclic aromatic hydrocarbons in smoked fish}

\author{
Duke Okoro and Temabor Nyerhovwo Ovuowo
}

DOI: https://doi.org/10.22271/chemi.2020.v8.i3b.9215

\begin{abstract}
PAHs whose source is attributable to anthropogenic activities have been determined in smoked fish obtained from markets in Effurun-Warri metropolis. The concentrations observed may be as a result of the smoking method employed. The objective of the study was to add to the database of the occurrences of PAHs in smoked food using Gas Chromatography with Flame Ionization Detector. The results did not show a pattern in the differences in total PAHs across the sampling points in the markets which may be due to variable smoking temperature. The compositional distribution of PAHs in all samples of the smoked Ethmalosa fimbriata showed the dominance of 2,3 - ring PAHs over the 4,5,6 - ring PAHs. This widespread in the total concentration of the 2,3-ring PAHs was observed in an earlier study of PAHs in smoked fish. Benzo(a)pyrene, a confirmed carcinogen had levels in the sampled smoked fish, which was found to be in excess of the maximum permissible limits of $0.005 \mathrm{mgkg}^{-1}$ established by the European Union. Although Benzo(a)pyrene was not detected at some sampling points. This is because the concentration and distribution of Benzo(a)pyrene in smoked fish may change during storage due to diffusion and degradation, as previously reported.
\end{abstract}

Keywords: Polycyclic aromatic hydrocarbons, smoked fish, Ethmalosa finbriatta

\section{Introduction}

Polyaromatic Hydrocarbons (PAHs) are organic compounds made up of multiple aromatic rings. PAHs are products of incomplete combustion from either organic substances or anthropogenic activities (Abdel-shafy, 2016) ${ }^{[1]}$. Anthropogenic activities such as the burning of wood, crop residues, and other biofuels are one of the factors that give rise to Polyaromatic Hydrocarbons in the environment. PAHs are chemically inert, non-polar and hydrophobic, but undergo metabolic activation in mammalian cells to diol-epoxides that bind to cellular macromolecules covalently, DNA thereby causing errors in DNA replication and mutations that initiate the carcinogenic process.

PAHs are found as complex mixtures throughout the environment (Ravindra et al, 2008) ${ }^{[18]}$, since studies reveal that PAHs make up the critical class of carcinogens. Previous studies show that there are at least 100 PAHs (Stołyhwo and Sikorski 2005) ${ }^{[21]}$, but the EU Scientific committee has identified 15 of these PAHs on food as genotoxic carcinogens. However, genotoxicity has not been proven (EC, 2002) ${ }^{[10]}$.

Smoking of food is a method of browning, cooking, or preserving food items by exposing them to fire from the burning of wood or charcoal. Smoking of food has been studied and reported to introduce Polyaromatic Hydrocarbons in food, which may lead to health risks. Several factors in the smoking process influence the composition of the smoke and the deposition of Polyaromatic Hydrocarbons in the food being smoked (Larsson, 1986) ${ }^{[13]}$. The temperature at which the combustion process occurs in the smoking of the food is of great importance. When fish is cooked over an open flame, PAHs are formed. Since the fish is in direct contact with the flame, pyrolysis of the fats in the fish generates PAHs that can become deposited on the fish. Nevertheless, fat dripping on to the flame had also been reported to generate the compounds which are then carried back onto the fish (Okoro and Ikolo, 2007) ${ }^{[6]}$. Bonga Fish (Ethmalosa fimbriata), when smoked, is one of the most popular fish products in West Africa. Smoking is carried out on Bonga fish in order to preserve it for a wider distribution and longevity. In Warri, Nigeria, the popular smoking method is the traditional fish smoking method (steel drums and wire gauze fuelled by wood).

Larsson (1982) ${ }^{[14]}$ investigated the level of 13 PAHs in samples of smoked fish using HighResolution Gas Chromatography (HRGC) with a Flame Ionization Detector. Forty-six samples 
from 20 commercial smokehouses were used for the study. In the study, 19 of the 46 samples showed concentrations of Benzo(a)pyrene higher than the $1 \mathrm{ug} / \mathrm{kg}$, but only one sample had a Benzo(a)pyrene level exceeding 5.0ug/kg. Wretling et al (2010) ${ }^{[24]}$ analysed the level of Benzo(a) pyrene and other PAHs present in 39 samples of smoked fish using HRGC-MS. Six out of 39 smoked fish samples showed Benzo(a) pyrene levels exceeding $5.0 \mathrm{ug} / \mathrm{kg}$.

Stołyhwo and Sikorski (2005) ${ }^{[21]}$ reported that wood smoke contains at least 100 PAHs and their related derivatives. Many of them are carcinogenic, and Benzo(a)pyrene is regarded as a marker of the carcinogenic PAHs in smoked fish. Traditional drum smoked fish samples were reported by Adeyeye et al (2015) ${ }^{[2]}$ to have high $\operatorname{Benzo(a)~pyrene~levels,~which~}$ exceeded the EU maximum permissible level of $5.0 \mathrm{ug} / \mathrm{kg}$ for Benzo(a) pyrene.

Erhunmwunse and Ekaye (2019) [9] investigated the carcinogenic and Genotoxicity of some PAHs in commonly consumed smoked fish and reported that Benzo(a)pyrene had an occurrence of $83.33 \%$ in all samples analysed.

Studies have been carried out to show the level of PAHs concentrations in smoked fish, but the need to contribute to the database of the occurrences of PAHs in smoked fish can not be over-emphasized. The objective of this study, therefore, is to determine the concentration of PAHs in samples of smoked Ethmalosa finbriatta (Bonga fish) consumed by the people of Effurun -Warri, Nigeria.

\section{Materials and Methods \\ Study Area}

Effurun-Warri metropolis. Effurun $\left(5.5624^{\circ} \mathrm{N}, 5.7800^{\circ} \mathrm{E}\right)$ and Warri $\left(5.5544^{\circ} \mathrm{N}, 5.7932^{\circ} \mathrm{E}\right)$ have fused as one municipal entity in two different Local Government Area (LGA) of Delta State. While Effurun is in Uvwie LAGA, Warri is in Warri South LGA. Samples of smoked Ethmalosa finbriata were obtained to enable a better representative sample that will reflect the environment of interest. The sampling points are Effurun market, Ogbe-Ijoh market, Igbudu market, and Warri Main market. These fish samples, as explained by the sellers, were caught and smoked from Sapele River, Ogulagha river in Forcados terminal, and Aladja waterside. EM1 - EM5 represents five smoked fish samples from Effurun market; OM1 - OM5 represents five smoked fish samples from Ogbe-Ijaw market; IM1- IM5 represents five smoked fish samples from Igbudu market; MM1 - MM5 represent five smoked fish samples from the Main market in Effurun-Warri metropolis. A google earth map showing the different markets in the study area is presented in figure 1 .

\section{Sampling, Handling, and Treatment}

Sampling was done in the Month of August, 2019 within a week interval. The five samples from each market were randomly sampled. The samples were collected and stored in aluminum foil bags. Quality assurance/quality control formed an integral part of the sampling process. A sample chain of custody forms was used for the registration and tracking of samples from the selling points to the laboratory. The homogenizing bucket was regularly cleaned after each random sampling. Aluminum foil sheet lining the bucket and the disposable hand- gloves were also regularly changed after each random sampling. In the laboratory, the samples were kept at below $4^{\circ} \mathrm{C}$ prior to treatment and laboratory analysis.

\section{Sample Preparation and Conditioning}

Sample preparation and conditioning was carried out as described by (Okoro and Ikolo, 2007) ${ }^{[6]}$

\section{Instrumental Analysis}

Gas Chromatography Operating Procedure.

Instrument Type: Gas chromatography HP5890 series. The basic GC parameters for the analysis of Polynuclear Aromatic Hydrocarbon were as follows: Injector Temp: $250{ }^{\circ} \mathrm{C}$; Temperature Program: Initial temp: $100{ }^{\circ} \mathrm{C}$; Initial time: 1; Rate 1: $4{ }^{\circ} \mathrm{C} / \mathrm{mins}$; Final Temp: $310^{\circ} \mathrm{C}$; Detector Temp: 300 ${ }^{\circ} \mathrm{C}$; Detector Type: FID; Column type: High Performance Capillary Column (HP-5, Crosslinked PH ME siloxane 19091J-413; Film thickness: 0.25 um, Length: 30m; Phase Ratio: 320 Column ID: 0.32mm; Carrier Gas: Helium; Inlet Mode: Splitless; Linear velocity =: $30 \mathrm{~cm} / \mathrm{sec}$.; Detector Type: Flame Ionization detector; Hydrogen: 35ml/min; Air: 350ml/min.; Data Acquisition System: Computerized system (chemstation) for collecting, storing and processing detector output.

\section{Initial Calibration and Calculation}

The GC-FID instrument was calibrated prior to sample analysis. This was done by injecting a series of PAH standards. The volume injected was $1 \mathrm{uL}$. A five-point calibration curve was prepared using the PAH standard mixture that was commercially obtained from Accustandard, USA. The range of the curve was $2.0 \mu \mathrm{g} / \mathrm{mL}$ to $20 \mu \mathrm{g} / \mathrm{mL}$. The response factor (RF) was calculated for each component of the PAH mixture standard using the area response and the amount of standard material. The relative standard deviation percentage (\%RSD) of the RF was calculated for each component across the calibration curve. The value was never in excess of $30 \%$ for the curve to be deemed valid. The recovery efficiencies for each PAHs were always $>70 \%$. The average response factor for the weight ranges was calculated and used for sample quantification. Identification of individual PAH compounds was performed by comparison of retention times of the standards with retention times of the identified substances.

\section{Results}

The sixteen EPA priority PAHs were analysed in 80 samples of smoked Ethmalosa fimbriata (Bonga fish). The levels of the individual PAHs and their mean \pm SD expressed in $\mathrm{mgkg}^{-1}$ are given in table $1-4$. Table 1 shows the levels of PAHs from five selling points in Effurun market (EM). The 16 PAHs were all identified in the samples except for low molecular-weight PAH such as fluorene which was not detected at EM1, EM2 and EM3, respectively. A high molecular-weight PAH such as benzo(k)fluoranthene was also not detected at point EM1, EM2, and EM3. 
Table 1: Levels of PAHs in Ethmalosa fimbriata (EM)

\begin{tabular}{|c|c|c|c|c|c|c|c|}
\hline Components (mg/kg) & EM 1 & EM 2 & EM 3 & EM 4 & EM 5 & Mean \pm SD & P-value \\
\hline Naphthalene & 0.64 & 0.84 & 0.12 & 1.08 & ND & $0.54 \pm 0.46$ & $>0.05$ \\
\hline Acenaphthylene & ND & 0.07 & 0.28 & ND & 0.35 & $0.14 \pm 0.16$ & $>0.05$ \\
\hline Acenaphthene & 0.01 & 0.1 & 0.05 & 0.06 & 0.16 & $0.08 \pm 0.06$ & $>0.05$ \\
\hline Fluorene & ND & ND & ND & 2 & ND & $0.40 \pm 0.90$ & $>0.05$ \\
\hline Phenanthrene & ND & ND & 12.38 & 3.11 & 0.03 & $3.10 \pm 5.36$ & $>0.05$ \\
\hline Anthracene & 1.01 & 1.01 & ND & 12 & 20 & $6.80 \pm 8.87$ & $>0.05$ \\
\hline Fluoranthene & ND & 0.04 & 6.08 & 9.87 & 0 & $3.20 \pm 4.56$ & $>0.05$ \\
\hline pyrene & ND & ND & 4.91 & 0.39 & 1.57 & $1.37 \pm 2.08$ & $>0.05$ \\
\hline Chrysene & 0.04 & ND & 0.85 & 6.62 & 0.29 & $1.56 \pm 2.85$ & $>0.05$ \\
\hline Benz(a)anthracene & 0.03 & ND & 0.02 & 0.59 & 0.06 & $0.14 \pm 0.25$ & $>0.05$ \\
\hline Benzo(b)fluoranthene & 0.02 & 0.01 & ND & 0.14 & 0.01 & $0.04 \pm 0.06$ & $>0.05$ \\
\hline Benzo(k)fluoranthrene & ND & ND & ND & 2.56 & ND & $0.51 \pm I .15$ & $>0.05$ \\
\hline Benzo(a)pyrene & ND & 0.01 & 0.06 & 10.23 & 0.07 & $2.07 \pm 4.56$ & $>0.05$ \\
\hline Dibenz(a,h)anthracene & 0.14 & 0.31 & 0.56 & 1.62 & 0.59 & $0.64 \pm 0.58$ & $>0.05$ \\
\hline Indeno(1,2,3-cd)pyrene & 0.6 & 0.42 & 0.42 & 4.49 & 0.65 & $1.32 \pm 1.78$ & $>0.05$ \\
\hline Benzo(g,h,i)perylene & 0.03 & 0.07 & ND & 1.01 & 0.11 & $0.24 \pm 0.43$ & $>0.05$ \\
\hline Total PAH & 2.52 & 2.88 & 25.73 & 55.77 & 23.89 & $22.16 \pm 21.81$ & $>0.05$ \\
\hline
\end{tabular}

$\mathrm{ND}=$ Not Detected; EM=Effurun Market; $\mathrm{SD}=$ Standard Deviation

Table 2: Levels of PAHs in Ethmalosa fimbriata (OM)

\begin{tabular}{|c|c|c|c|c|c|c|c|}
\hline Components mg/kg & OM 1 & OM 2 & OM 3 & OM 4 & OM 5 & Mean \pm SD & P-value \\
\hline Naphthalene & 0.10 & 0.01 & ND & 0.24 & 0.31 & $0.13 \pm 0.14$ & $>0.05$ \\
\hline Acenaphthylene & 0.07 & 0.10 & 0.27 & 0.19 & ND & $0.13 \pm 0.11$ & $>0.05$ \\
\hline Acenaphthene & 0.13 & 0.01 & 0.03 & 0.09 & 0.28 & $0.11 \pm 0.10$ & $>0.05$ \\
\hline Fluorene & ND & ND & ND & ND & ND & ND & $<0.05$ \\
\hline Phenanthrene & ND & ND & 0.05 & 0.92 & 0.01 & $0.20 \pm 1.40$ & $>0.05$ \\
\hline Anthracene & 1.28 & 48.85 & 45.04 & 33.50 & 1.62 & $26.06 \pm 23.17$ & $>0.05$ \\
\hline Fluoranthene & 0.02 & 0.06 & ND & 0.01 & ND & $0.02 \pm 0.03$ & $<0.05$ \\
\hline pyrene & ND & 1.48 & 1.44 & 3.35 & 0.01 & $1.26 \pm 1.38$ & $>0.05$ \\
\hline Chrysene & ND & 0.18 & 0.69 & 0.94 & ND & $0.36 \pm 0.43$ & $>0.05$ \\
\hline Benz(a)anthracene & 0.05 & 0.07 & 0.04 & 0.28 & ND & $0.09 \pm 0.11$ & $>0.05$ \\
\hline Benzo(b)fluoranthene & ND & ND & ND & 0.03 & 0.01 & $0.01 \pm 0.01$ & $<0.05$ \\
\hline Benzo(k)fluoranthrene & ND & ND & ND & ND & ND & ND & $<0.05$ \\
\hline Benzo(a)pyrene & 0.10 & 0.13 & 0.01 & ND & 0.02 & $0.05 \pm 0.06$ & $>0.05$ \\
\hline Dibenz(a,h)anthracene & 0.10 & 0.10 & 0.13 & 0.53 & 0.19 & $0.21 \pm 0.18$ & $>0.05$ \\
\hline Indeno(1,2,3-cd)pyrene & 0.22 & 0.44 & 0.80 & 0.31 & 0.55 & $0.46 \pm 0.23$ & $>0.05$ \\
\hline Benzo(g,h,i)perylene & 0.07 & 0.10 & ND & 0.02 & 0.01 & $0.04 \pm 0.04$ & $>0.05$ \\
\hline Total PAH & 2.14 & 51.53 & 48.50 & 40.41 & 3.01 & $29.13 \pm 24.57$ & $>0.05$ \\
\hline
\end{tabular}

$\mathrm{ND}=$ Not Detected; OM=Ogbe-Ijaw Market; $\mathrm{SD}=$ Standard Deviation

Table 3: Levels of PAHs in Ethmalosa fimbriata (IM)

\begin{tabular}{|c|c|c|c|c|c|c|c|}
\hline Components mg/kg & IM 1 & IM 2 & IM 3 & IM 4 & IM 5 & Mean \pm SD & P-value \\
\hline Naphthalene & 0.74 & ND & 0.12 & 1.42 & 0.05 & $0.47 \pm 0.61$ & $>0.05$ \\
\hline Acenaphthylene & 0.97 & ND & ND & 0.19 & 0.04 & $0.24 \pm 0.41$ & $>0.05$ \\
\hline Acenaphthene & 0.69 & ND & 0.42 & 0.18 & 0.53 & $0.36 \pm 0.28$ & $>0.05$ \\
\hline Fluorene & ND & 0.06 & ND & ND & ND & $0.01 \pm 0.02$ & $<0.05$ \\
\hline Phenanthrene & ND & 0.07 & 0.01 & 0.03 & ND & $0.02 \pm 0.03$ & $<0.05$ \\
\hline Anthracene & 0.02 & 2.26 & 12.87 & 16.05 & ND & $6.24 \pm 7.64$ & $>0.05$ \\
\hline Fluoranthene & 0.13 & 0.22 & ND & 0.19 & 1.73 & $0.45 \pm 0.72$ & $>0.05$ \\
\hline pyrene & 1.40 & 0.08 & 0.11 & 0.68 & 4.68 & $1.39 \pm 1.92$ & $>0.05$ \\
\hline Chrysene & 0.05 & ND & ND & ND & 0.92 & $0.19 \pm 0.40$ & $>0.05$ \\
\hline Benz(a)anthracene & ND & ND & ND & ND & 0.25 & $0.05 \pm 0.11$ & $>0.05$ \\
\hline Benzo(b)fluoranthene & 0.40 & 0.01 & 0.34 & ND & ND & $0.15 \pm 0.20$ & $>0.05$ \\
\hline Benzo(k)fluoranthrene & 0.07 & ND & 0.30 & ND & ND & $0.07 \pm 0.13$ & $>0.05$ \\
\hline Benzo(a)pyrene & 0.07 & 0.05 & 0.46 & ND & ND & $0.11 \pm 0.19$ & $>0.05$ \\
\hline Dibenz(a,h)anthracene & 0.18 & 0.67 & 0.54 & 0.21 & 0.39 & $0.40 \pm 0.21$ & $>0.05$ \\
\hline Indeno(1,2,3-cd)pyrene & 0.65 & 0.34 & 0.52 & 0.87 & 0.42 & $0.56 \pm 0.21$ & $>0.05$ \\
\hline Benzo(g,h,i)perylene & 1.11 & 0.42 & 0.89 & 0.15 & 0.35 & $0.58 \pm 0.40$ & $>0.05$ \\
\hline Total PAH & 6.48 & 4.18 & 16.58 & 19.97 & 9.36 & $11.32 \pm 6.73$ & $>0.05$ \\
\hline
\end{tabular}

$\mathrm{ND}=$ Not Detected; IM=Igbudu Market; $\mathrm{SD}=$ Standard Deviation 
Table 4: Levels of PAHs in Ethmalosa fimbriata (MM)

\begin{tabular}{|c|c|c|c|c|c|c|c|}
\hline Components (mg/kg) & MM1 & MM2 & MM 3 & MM 4 & MM 5 & Mean \pm SD & p-value \\
\hline Naphthalene & 0.07 & 0.64 & 0.04 & 0.29 & 0.12 & $0.23 \pm 0.24$ & $>0.05$ \\
\hline Acenaphthylene & 1.53 & 1.05 & 0.44 & 1.47 & 0.56 & $1.01 \pm 0.50$ & $>0.05$ \\
\hline Acenaphthene & 0.54 & 0.30 & 0.15 & 0.43 & 0.25 & $0.33 \pm 0.15$ & $>0.05$ \\
\hline Fluorene & ND & ND & ND & 0.14 & ND & $0.03 \pm 0.06$ & $>0.05$ \\
\hline Phenanthrene & ND & ND & ND & ND & 0.02 & ND \pm 0.01 & $<0.05$ \\
\hline Anthracene & 0.03 & 0.03 & 29.47 & 0.01 & 31.12 & $12.13 \pm 16.59$ & $>0.05$ \\
\hline Fluoranthene & 0.67 & 1.12 & 0.05 & 5.34 & 0.35 & $1.50 \pm 2.18$ & $>0.05$ \\
\hline pyrene & 3.50 & 2.41 & 1.08 & 3.66 & 0.88 & $2.31 \pm 1.30$ & $>0.05$ \\
\hline Chrysene & 1.10 & 0.86 & 0.03 & 1.05 & 0.34 & $0.68 \pm 0.47$ & $>0.05$ \\
\hline Benz(a)anthracene & ND & 0.25 & ND & 0.36 & 0.10 & $0.14 \pm 0.16$ & $>0.05$ \\
\hline Benzo(b)fluoranthene & 0.01 & 0.06 & ND & 0.02 & 0.02 & $0.02 \pm 0.02$ & $<0.05$ \\
\hline Benzo(k)fluoranthrene & ND & ND & ND & ND & ND & ND & $<0.05$ \\
\hline Benzo(a)pyrene & 0.01 & ND & 0.04 & ND & ND & $0.01 \pm 0.02$ & $<0.05$ \\
\hline Dibenz(a,h)anthracene & 0.56 & 0.34 & 0.22 & 0.15 & 0.40 & $0.43 \pm 0.32$ & $>0.05$ \\
\hline Indeno(1,2,3-cd)pyrene & 0.88 & 0.07 & 0.12 & 0.15 & 0.90 & $0.34 \pm 0.30$ & $>0.05$ \\
\hline Benzo(g,h,i)perylene & 0.19 & 0.35 & 0.35 & 0.07 & 0.06 & $0.20 \pm 0.14$ & $>0.05$ \\
\hline Total PAH & 9.09 & 7.48 & 31.99 & 13.14 & 35.12 & $15.43 \pm 11.35$ & $>0.05$ \\
\hline
\end{tabular}

$\mathrm{ND}=$ Not Detected; $\mathrm{MM}=$ Main Market; $\mathrm{SD}=$ Standard Deviation

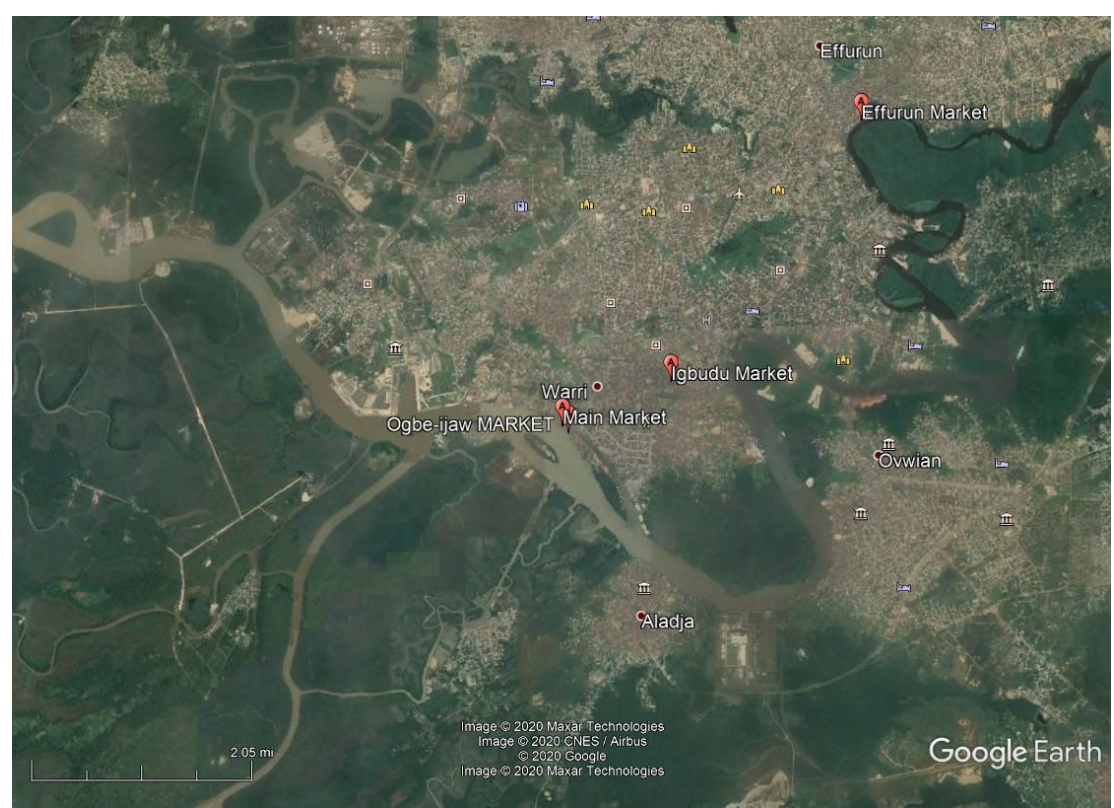

Fig 1: Map of study area showing Markets in

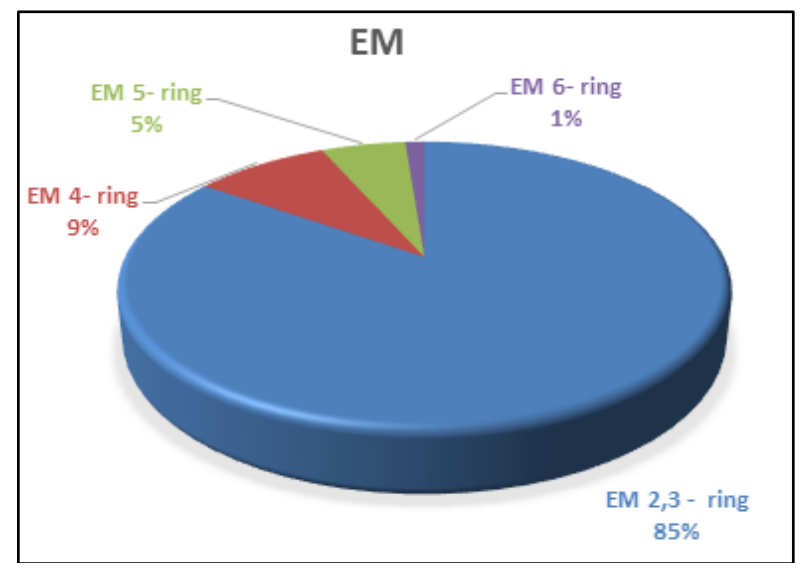

Fig 2: Compositional distribution of PAHs in smoked Ethmalosa fimbriata (EM)

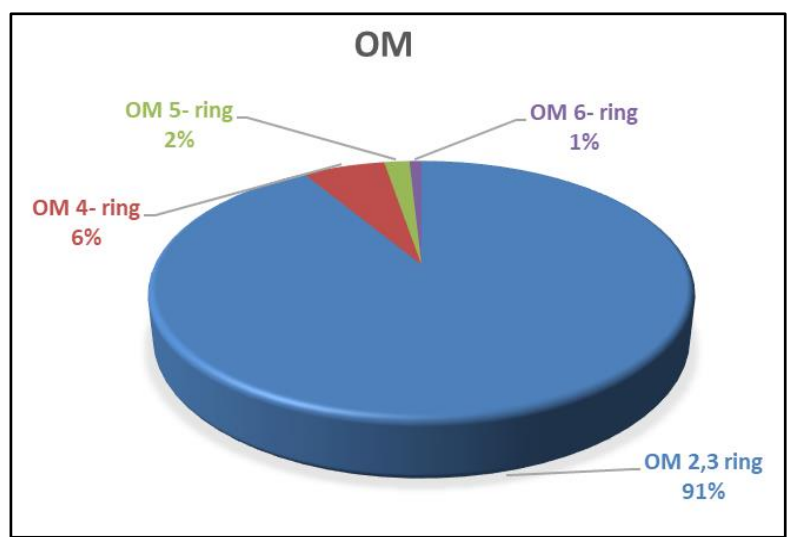

Fig 3: Compositional distribution of PAHs in smoked Ethmalosa fimbriata $(\mathrm{OM})$ 


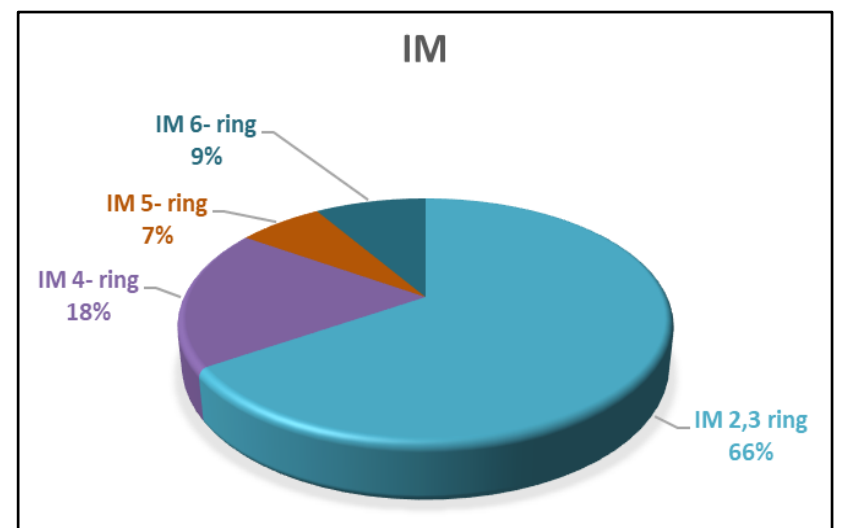

Fig 4: Compositional distribution of PAHs in smoked Ethmalosa fimbriata (IM)

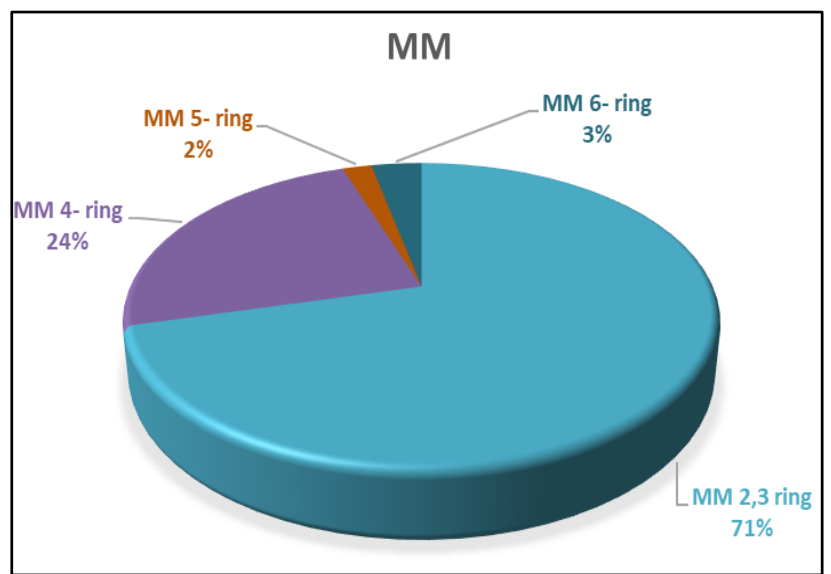

Fig 5: Compositional distribution of PAHs in smoked Ethmalosa fimbriata $(\mathrm{MM})$

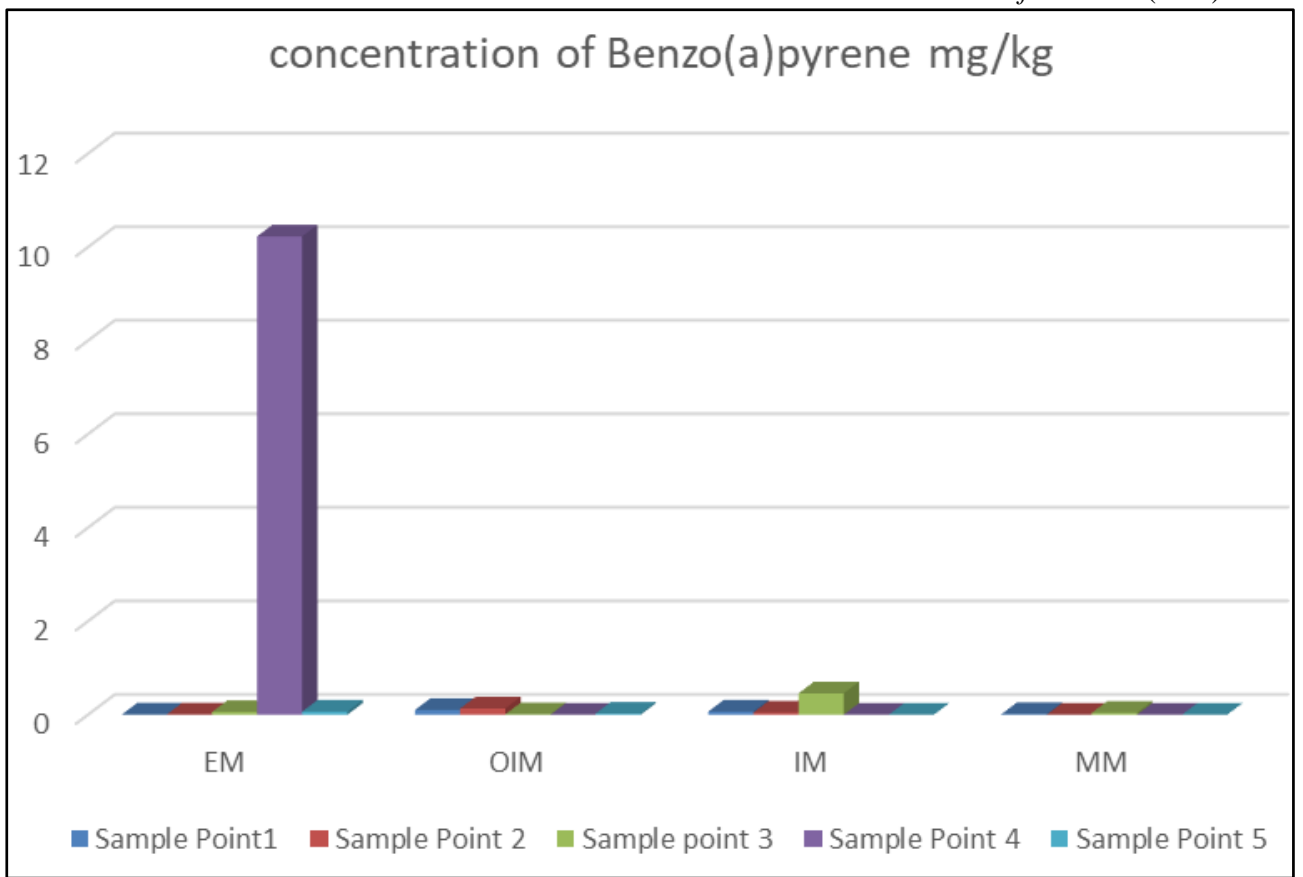

Fig 6: Concentration of Benzo(a)pyrene in smoked Ethmalosa fimbriata from the sampling stations.

The concentration of total PAHs at EM was given as $22.16 \pm 21.81 \mathrm{mgkg}^{-1}$. There was no significant difference in the levels across the five-sampling points at EM $(\mathrm{P}>0.05)$. Table 2 shows the level of PAHs from five sampling points in Ogbe-Ijaw market (OM) with a low molecular-weight PAH such as fluorene and a high molecular-weight PAH such as benzo(k)fluoranthene not detected at the five sampling points. The total PAHs concentration at OM was given as $29.13 \pm 25$ $\mathrm{mgkg}^{-1}$. However, there was a significant difference in the levels of fluorene, fluoranthene, benzo(b)fluoranthene, and benzo(k)fluoranthene with a $\mathrm{p}$-value of $<0.05$. Anthracene showed significantly high levels at the different sampling points with observable values of $1.28 \mathrm{mgkg}^{-1}, 48.85 \mathrm{mgkg}^{-1}$, $45.04 \mathrm{mgkg}^{-1}, 33.49 \mathrm{mgkg}^{-1}$ and $1.61 \mathrm{mgkg}^{-1}$. Table 3 shows the levels of PAHs from five-sampling points in Igbudu market (IM) with low molecular-weight PAHs such as acenapthylene and fluorene not detected at points IM2, IM3 and IM1, IM3, IM5 respectively. Moderate molecular-weight PAHs such as chrysene and benz(a)anthracene were not detected at points IM2, IM3, IM4 and IM1, IM2, IM3, IM4, respectively. High molecular weight PAHs such as benzo(k)fluoranthene and benzo(a)pyrene were not also detected at points IM2, IM4, IM5, and IM4, IM5, respectively. The concentration of total PAH at IM was given as $11.32 \pm 6.73 \mathrm{mgkg}^{-1}$, but there was a significant difference in the levels of fluorene and phenanthrene with a p-value of $<0.05$. Table 4 shows the levels of PAHs from five sampling points in Main Market (MM) with low molecular weight PAHs such as fluorene and phenanthrene not detected at points MM1, MM2, MM3, MM5 and MM1, MM2, MM4. High molecular-weight PAHs such as benzo(k)fluoranthene and benzo(a)pyrene were also not detected at points MM1 MM5 and MM2, MM4, MM5 respectively, but there was a significant difference in the levels of fluorene, benzo(b)fluoranthene, benzo(k)fluoranthene and benzo(a)pyrene with p-value of $<0.05$. Generally, the results from the four markets show that the level of anthracene was significantly high since they exceed the $0.002 \mathrm{mgkg}^{-1}$ maximum permissible limits established by the European Union. The difference between the concentration of Total $\mathrm{PAH}$ across the surveyed markets was statistically insignificant at $95 \%$ confidence level ( $p>0.05)$.

The compositional analysis of the different sizes of the rings was given in Fig 1-4. In all sampling points, the 2,3-ring Polyaromatic hydrocarbons dominated the levels detected. 2,3-rings PAHs; naphthalene, acenaphthelene, acenaphthene, Fluorene, phenanthrene, and anthracene were prevalent with $85 \%, 91 \%, 66 \%$ and $71 \%$ for sampling points EM, OM, IM, 
and MM respectively. This was followed by 4-ring polyaromatic hydrocarbons; fluoranthene, pyrene, benzo(a)anthracene and chrysene recording 24\%, 18\%, 6\%, and $9 \%$ for EM, OM, IM, and MM sampling points. The compositional distribution of 5-rings and 6-rings size of PAHs showed variations in sampling points IM and MM. The percentage of 5-ring size PAH in sampling points IM and MM is $7 \%$ and $2 \%$ while the 6-ring size PAHs in sampling points IM and $\mathrm{MM}$ is $9 \%$ and $3 \%$. The concentrations of Benzo(a)pyrene of the smoked Ethmalosa fimbriata from the different sampling points was given in figure 5. The level of Benzo(a)pyrene from EM4 was predominately high with $10.23 \mathrm{mgkg}^{-1}$. MM sampling station is seen to record the lowest levels of Benzo(a)pyrene.

\section{Discussion}

The variation in the concentrations of the individual PAHs of the smoked Ethmalosa fimbriata from the four sampling stations could be attributable to the different methods employed by the fish vendors in the preparation and preservation processes of the fish. The total PAHs observed in this study was compared with the PAHs in smoked fish from similar studies (Igwe et al, 2012; Yusulf et al, 2015; Silva et al, 2011 and Palm et al, 2011) [12, 15, 20, 17] whom reported varying concentrations of PAHs in different species of smoked fish in Nigeria including Ethmalosa fimbriata. The total level of PAHs with range $(11.32-29.13 \mathrm{mgkg}-1)$ from this study was observed to be higher than the reported concentrations. The exceedances may be attributable to the smoking temperature, method, time, and the fat content of the fish. Information from the fish vendors has it that the fishes were re-smoked at different times to enable them to stay preserved until the point of sales. The maximum mean total PAHs $29.13 \pm 24.57 \mathrm{mgkg}^{-1}$ from this study was quite higher than the maximum mean total PAHs reported by (Essumang et al 2012; Deudahi-Oleisen et al, 2006) ${ }^{[7,5]}$. This may be attributable to the intense smoking process required in preparing Ethmalosa fimbriata, which involves direct exposure of hot smoke from the burning wood fire (Tongo et al 2017) ${ }^{[22]}$. The basic process of smoking fish in the study area in Nigeria is by heating the fish over a burning wood which generates wood smoke Stołyhwo and Sikorski (2005) [21] and wood smoke have been reported to contain a large number of PAHs (Tongo et al, 2017) ${ }^{[22]}$

The results from the four markets show that the level of anthracene was significantly high at all sampling points with the range $6.24-18.64\left(\mathrm{mgkg}^{-1}\right)$ exceeding the permissible limits of PAHs by the European Union (EC, 2002) ${ }^{[10]}$. Its levels were generally the highest among the PAHs. Anthracene is seen as a probable human carcinogen, but not enough information exists to classify anthracene as a cancercausing substance (US EPA, 2017) [23]. According to Stolyhwo and Sikorski (2005) [21] PAHs differs in carcinogenic potency but those regarded as not being carcinogenic may function in living organisms as synergists, increasing the carcinogenetic of other PAHs.

The compositional distribution of PAHs in all samples of the smoked Ethmalosa fimbriata showed the prevalence of 2,3ring PAHs in percentage over the 4,5,6 - ring PAHs. This widespread in the total concentration of the 2,3-ring PAHs was observed in an earlier study of PAHs in smoked fish (Iwegbue et al., 2018) ${ }^{[4]}$. The results from this study are in line with the study of Zelinkova and Wenzi (2015) ${ }^{[26]}$, which showed that the most prevalent PAHs in foodstuffs are the low molecular weight PAHs, particularly the 2,3-ring PAHs.
High level of low molecular-weight PAHs indicates that the process of smoking contributes significantly to the increased percentage composition of low molecular weight PAHs compared to high molecular-weight PAHs (Mahugija et al., 2018) ${ }^{[15]}$. Results from this study also agree with the study of (Iwegbue et al, 2018; Igwe et al 2012) [4, 12] whose compositional pattern of PAHs in the fish species showed the predominance of 2-4 ring PAHs 0ver 5-6 ring PAHs. It was observed that the results from this study contrast the results from Erhunmunse and Ekaye (2019) ${ }^{[9]}$ with higher molecular weight PAHs occurring more than low molecular weight PAHs.

Benzo(a)pyrene concentrations in the sampled smoked Ethmalosa fimbriata was found to exceed the maximum permissible limits of $0.005 \mathrm{mgkg}^{-1}$ established by the European Union. Benzo(a)pyrene is used as an indicator of the occurrence, structure, and effects of the carcinogenic PAHs in food (EC, 2002) ${ }^{[10]}$. The concentration of benzo(a)pyrene in all the sampling points ranged from $0.00-$ $10.23 \mathrm{mgkg}^{-1}$. The exceptionally high benzo(a)pyrene levels in EM4 station may be attributable to variable smoking temperature. benzo(a)pyrene was not detected at some sampling points. This is because the concentration and distribution of benzo(a)pyrene in smoked fish may change during storage due to diffusion and degradation (Simko, 1990).

\section{Conclusion}

The Occurrences of PAHs in smoked Ethmalosa fimbriata sold in various markets of Effurun-Warri metropolis has been documented. The exceedances of the PAHs notably the carcinogenic benzo(a)pyrene compared to regulatory guidelines of the European Commission, may be attributable to the smoking methods. However, further studies could focus on the smoking methods, preservation, and regulating the temperature of smoking to investigate if the PAHs imparted on the smoked fish will be detrimental to health.

\section{Acknowledgment}

The authors wish to acknowledge the Research and Development (R \& D) unit of Dukoria International Limited for granting their laboratory for sample preservation, extraction, and GC-FID analysis.

\section{References}

1. Abdel-Shafy, Hussein I. "A review on polycyclic aromatic hydrocarbons: Source, environmental impact, effect on human health and remediation". Egyptian Journal of Petroleum. 2016; 25(1):107-123. doi:10.1016/j.ejpe.2015.03.011.

2. Adeyeye SAO, Oyewole OB, Obadina AO, Omemu AM, Oyedele HA, Adeogun SO. A survey on traditional fish smoking and the socio-economic status of the fish processors in Lagos State, Nigeria. African Journal of Food Science. 2015; 9(2):59-64 DOI: 10.5897/AJFS2014.1216

3. Akpambang VOE, Purcaro G, Lajide L, Amoo IA, Conte LS, Moret S. Determination of polycyclic aromatic hydrocarbons (PAHs) in commonly consumed Nigerian smoked/grilled fish and meat. Journal of food additives and contaminants: Part A. 2009; 26(7): DOI: 10.1080/02652030902855406

4. Iwegbue CMA, Odogbor, Egobueze DFE, Emoyan OO, Eze GOT, Odali W et al. Polycyclic Aromatic Hydrocarbons in Smoked Ethmalosa fimbriata and 
Gymnarchus niloticus from Selected Fish Markets in the Niger Delta, Nigeria, Polycyclic Aromatic Compounds, 2018. DOI: 10.1080/10406638.2018.1550794

5. Duedahl-Olesen L, White S, Binderup ML. Polycyclic aromatic hydrocarbons (PAH) in Danish smoked fish and meat products. Journal of polycyclic aromatic compounds 2006; 26(3):163-184 DOI: 10.1080/10406630600760527

6. Okoro D, Ikolo AO. Polynuclear aromatic hydrocarbons concentrations In char-broiled meat "Suya" Journal of applied sciences 2007; 7(14):1873-1879 DOI: 0.3923/jas.2007.1873.1879

7. Essumang DK, Dodoo DK, Adjei JK. Polycyclic aromatic hydrocarbon (PAH) contamination in smokedcured fish products. Journal of food composition and analysis. 2012; 27(2):128-138 DOI: 10.016/j.fca.2012.04.007

8. Essumang DK, Dodoo DK, Adjei JK. Effect of smoke generation sources and smoke curing duration on the levels of polycyclic aromatic hydrocarbons (PAH) in different suites of fish. Food Chem. Toxicol. 2013; 58:86-94

9. Erhunmwunse NO, Ekaye SA. Carcinogenic and genotoxicity of some PAHs in commonly consumed smoked fish (Parachanna obscura and Ethmalosa fimbriata) J. Appl. Sci. Environ. Manage. 2019; 23(7):1349-1352

Doi: https://dx.doi.org/10.4314/jasem.v23i7.24

10. EC. Europen Commission (2002) Opinion of the scientific committee on food on the risk to human health of polycyclic aromatic hydrocarbons in food SCF/CS/RNTM/PAH/29, 2002.

11. Iwugbue CMA, Aganbi OE, Ogala JE, Omo-Irabor OO, Martincigh BS. Concentration and health risk assessment of polycyclic aromatic hydrocarbons in soils of an urban environment in the Niger Delta, Nigeria. Toxicol. Environ. Health Sci. 2016; 8(3):221-233

12. Igwe JC, Odo EO, Okereke SE, Asuquo EE, Nnorom IC, Okpareke OC. Levels of polycyclic aromatic hydrocarbons (PAHs) in some fish samples from Mushin area of Lagos, Nigeria: effects of smoking Terrestial Aquat. Environ. Toxicol. 2012; 6(1):30-35

13. Larsson BK. Polycyclic aromatic hydrocarbons in Swedish foods: Aspects on analysis, occurrence and intake. Uppsala, Swedish Food Research Department, The National Food Administration, 1986, 60.

14. Larsson BK. Polycyclic aromatic hydrocarbons in smoked fish. Zeitschrift fürLebensmittel-Untersuchung und-Forschung. 1982; 174:101-107.

15. Mahugija M. Levels of polycyclic aromatic hydrocarbons (PAHs) in smoked and sun-dried fish samples from area in lake Victoria Mwanza, Tanzania. Journal of food composition and analysis. 2018; 73:39-46 DOI: 10.1016/j.fca.2018.07.010

16. Ofomata I, Obodoechi LO, Obidike RI, Nwanta JA. Presence and levels of concentration of polycyclic aromatic hydrocarbons (PAHS) in smoked fish, hides and skin of slaughter cattle and goats in Akwa urban, Nigeria. International journal of current pharmaceutical research 2019; 11(2):14-17

17. Palm LMN, Carboo D, Yeboah PO, Quasie WJ, Gorleku A, Darko A. Characterization of polycyclic aromatic hydrocarbons (PAHs) present in smoked fish from Ghana. Adv. J Food Sci. Technol. 2011; 3(5): 332-338

18. Ravindra K, Sokhi R, Van Grieken R. Atmospheric polycyclic aromatic hydrocarbons: Source attribution, emission factors and regulation. Atmospheric Environment. 2008; 42(13):2895-2921. Bibcode: 2008AtmEn..42.2895R.

doi:10.1016/j.atmosenv.2007.12.010. hdl:2299/1986. ISSN 1352-2310.

19. Simko P. Changes of Benzo(a)pyrene contents in smoked fish during storage. Food chemistry. 1991; 40(3):293-300 DOI: $10.1016 / 0308-8146(91) 90113-3$

20. Silva BO, Adetunde OT, Oluseyi TO, Olayinka KO, Alo BI. Effects of the methods of smoking on the levels of polycyclic aromatic hydrocarbons (PAHs) in some locally consumed fishes in Nigeria. African J. Food Sci., 2011; 5(7):384-391.

21. Stolyhwo A, Sikorski ZE. Polycyclic aromatic hydrocarbons in smoked fish: A critical review. Food Chem., 2005; 91:303-311

22. Tongo I, Ozekek O, Ezemonye LIN. Human Health Risk Assessment of Polycyclic Aromatic Hydrocarbons (PAHs) in Smoked Fish Species from Markets in Southern Nigeria. Toxicol. Rep 2017; 4:55-61 DOI: 10.1016/j.toxrep.2016.12.006

23. US EPA. United States Environmental Protection Agency (2017) Anthracene - EPA Archive. Retrieved from archive.epa.gov, 2017.

24. Wretling S, Eriksson A, Eskhult GA, Larsson B. Polycyclic aromatic hydrocarbons (PAHs) in Swedish smoked meat and fish. Journal of food composition and analysis. 2010; 23(3):264-272

25. Yusuf APA, Ezechukwu KA, Fakoya LA, Akintola SL, Agboola JI, Omoleye TO. Influence of fish smoking methods on Polycyclic Aromatic Hydrocarbon content and possible risks to Human Health. Afr. J Food Sci. 2015; 9(3):126-135

26. Zelinkova Z, Wenzi T. The occurrence of 16 EPA PAHs in food - a review. Polycyclic Aromatic Compounds, 2014, 2015; 35:248-284.

doi: $10.1080 / 10406638.2014 .918550$ 